\title{
TEKNOLOGI PRODUKSI INTENSIF TOKOLAN UDANG WINDU (Penaeus monodon Fabr.) DI TAMBAK DENGAN SISTEM AERASI
}

\author{
Hidayat Suryanto Suwoyo*) dan Markus Mangampa*) \\ ${ }^{*}$ Balai Riset Perikanan Budidaya Air Payau, Maros
}

\begin{abstract}
ABSTRAK
Sampai saat ini udang masih merupakan komoditas andalan untuk meningkatkan devisa ekspor non-migas. Namun masalah penyakit masih menjadi kendala utama yang dihadapi petambak, sementara cara penanggulangan yang efektif belum ditemukan. Salah satu alternatif yang terus dikaji dan dikembangkan untuk menanggulangi penyakit adalah melalui penggunaan benur berkualitas. Mutu benur dan kesalahan manajemen pakan dapat diatasi dengan penggunaan benur hasil pentokolan. Pentokolan dengan sistem aerasi merupakan salah satu alternatif. Keuntungan pentokolan ini adalah dapat diperoleh benur yang berkualitas tinggi sehingga meningkatkan vitalitas benur, yang akhirnya dapat meningkatkan produktivitas tambak, efisiensi penggunaan pakan, wadah dan pengelolaan, mempersingkat waktu pemeliharaan, sehingga mengurangi peluang terserangnya penyakit. Sintasan tokolan dihasilkan dengan sistem aerasi ini dapat mencapai sekitar $82,65 \%-92,36 \%$ dengan rata-rata $85,79 \%$ dan bobot akhir berkisar antara 0,229--0,331 g/ekor.
\end{abstract} KATA KUNCI: tokolan, aerasi, tambak,
sintasan, udang windu

\section{PENDAHULUAN}

Sampai saat ini udang masih merupakan komoditas andalan untuk meningkatkan devisa ekspor non-migas. Puncak keberhasilan dan produksi udang budidaya di tambak yang menciri pada volume ekspor udang terjadi pada tahun 1992 yang mencapai lebih dari 100.000 MT atau senilai dari US\$760.000. Sejak tahun 1992 produksi udang budidaya tambak cenderung terus menurun hingga mencapai titik mendatar sekitar 87.000 MT (Ditjenkan, 1995 dalam Ahmad, 1999). Sedangkan Sugama (2002) melaporkan bahwa sejak tahun 1995 budidaya udang windu mengalami penurunan produksi dari 100.000 M T menjadi 80.000 MT pada tahun 2001.

Masalah penyakit udang masih menjadi kendala utama yang dihadapi petambak sekarang ini, sementara cara penanggulangan yang efektif belum ditemukan. Pada umumnya di tambak, sekali udang terserang penyakit maka sulit untuk diatasi dan yang sering terjadi adalah kematian total, atau udang terpaksa dipanen sebelum mencapai ukuran yang paling menguntungkan (Ahmad, 1999). Di samping itu tekanan yang semakin berat terhadap ekosistem pesisir akibat pembangunan di berbagai sektor menghasilkan dampak dalam bentuk penurunan mutu lingkungan budidaya udang, karena kesalahan dalam penerapan manajemen budidaya dan penerapan teknologi itu sendiri (Tonnek et al., 2002).

Upaya penanggulangan kegagalan panen tersebut hingga saat ini terus dikaji dan dicarikan alternatif pemecahannya. Salah satu alternatif yang terus dikaji dan dikembangkan adalah bagaimana menanggulangi penyakit secara baik melalui penggunaan benur berkualitas. Mutu benur dan kesalahan manajemen pakan dapat diatasi dengan penggunaan benur hasil pentokolan. Keuntungan pentokolan adalah dapat diperoleh benur yang berkualitas tinggi sehingga meningkatkan vitalitas benur, yang akhirnya dapat meningkatkan produktivitas tambak, efisiensi penggunaan pakan, wadah dan pengelolaan, mempersingkat waktu pemeliharaan di tambak pembesaran sehingga mengurangi peluang terserangnya penyakit (Mangampa et al., 1990; Gunarto et al., 2002). Berdasarkan hal tersebut maka dilakukan kegiatan produksi tokolan udang windu di tambak dengan kepadatan tinggi yang menggunakan aerasi, dan akhirnya diperoleh suatu teknologi produksi tokolan udang windu yang efisien dengan asumsi mencapai sintasan yang optimal.

\section{KONSTRUKSI TAMBAK}

Secara umum konstruksi tambak merupakan perencanaan bentuk yang meliputi ukuran panjang dan lebar petakan, kedalaman air dalam petakan, penempatan aerasi, dan letak pintu pemasukan dan keluarnya air. Konstruksi diarahkan agar tambak dapat berfungsi secara efisien dan layak secara ekonomis tanpa mengabaikan kebutuhan biologis udang yang dipelihara. Petakan tambak sebaiknya berbentuk empat persegi panjang atau bujur sangkar (Gambar 1). Untuk petakan berbentuk persegi panjang sebaiknya sejajar arah angin. Hal ini dimaksudkan 